\title{
Membrane Transporters Involved in the Antimicrobial Activities of Pyrithione in Escherichia coli
}

\author{
Jesus Enrique Salcedo-Sora ${ }^{1, * \mathbb{D}}$, Amy T. R. Robison ${ }^{2}$, Jacqueline Zaengle-Barone ${ }^{2}$, Katherine J. Franz ${ }^{2, *(D)}$ and \\ Douglas B. Kell 1,3,*(D) \\ 1 Department of Biochemistry and Systems Biology, Institute of Systems, Molecular and Integrative Biology, \\ University of Liverpool, Crown St., Liverpool L69 7ZB, UK \\ 2 Department of Chemistry, Duke University, 124 Science Drive, Durham, NC 27708, USA; \\ amy.robison@duke.edu (A.T.R.R.); jacqueline.zaengle@duke.edu (J.Z.-B.) \\ 3 Novo Nordisk Foundation Centre for Biosustainability, Technical University of Denmark, Building 220, \\ Kemitorvet, 2800 Kgs Lyngby, Denmark \\ * Correspondence: j.salcedo-sora@liverpool.ac.uk (J.E.S.-S.); katherine.franz@duke.edu (K.J.F.); \\ dbk@liverpool.ac.uk (D.B.K.)
}

Citation: Salcedo-Sora, J.E.; Robison, A.T.R.; Zaengle-Barone, J.; Franz, K.J.; Kell, D.B. Membrane Transporters Involved in the Antimicrobial Activities of Pyrithione in Escherichia coli. Molecules 2021, 26, 5826. https:// doi.org/10.3390/molecules26195826

Academic Editor: Mary

K. Phillips-Jones

Received: 29 July 2021

Accepted: 20 September 2021

Published: 26 September 2021

Publisher's Note: MDPI stays neutral with regard to jurisdictional claims in published maps and institutional affiliations.

Copyright: (c) 2021 by the authors. Licensee MDPI, Basel, Switzerland. This article is an open access article distributed under the terms and conditions of the Creative Commons Attribution (CC BY) license (https:// creativecommons.org/licenses/by/ $4.0 /)$.

\begin{abstract}
Pyrithione (2-mercaptopyridine-N-oxide) is a metal binding modified pyridine, the antibacterial activity of which was described over 60 years ago. The formulation of zinc-pyrithione is commonly used in the topical treatment of certain dermatological conditions. However, the characterisation of the cellular uptake of pyrithione has not been elucidated, although an unsubstantiated assumption has persisted that pyrithione and/or its metal complexes undergo a passive diffusion through cell membranes. Here, we have profiled specific membrane transporters from an unbiased interrogation of 532 E. coli strains of knockouts of genes encoding membrane proteins from the Keio collection. Two membrane transporters, FepC and MetQ, seemed involved in the uptake of pyrithione and its cognate metal complexes with copper, iron, and zinc. Additionally, the phenotypes displayed by CopA and ZntA knockouts suggested that these two metal effluxers drive the extrusion from the bacterial cell of potentially toxic levels of copper, and perhaps zinc, which hyperaccumulate as a function of pyrithione. The involvement of these distinct membrane transporters contributes to the understanding of the mechanisms of action of pyrithione specifically and highlights, more generally, the important role that membrane transporters play in facilitating the uptake of drugs, including metal-drug compounds.
\end{abstract}

Keywords: pyrithione; metal ions; membrane transporters; gram-negative; E. coli; Keio collection; copper; zinc; iron

\section{Introduction}

The rise of antimicrobial resistance is a major public health issue [1-11], and understanding its basis is key to overcoming it. While efflux pumps constitute one important source of resistance [12-21], another is based on enzymes-such as $\beta$-lactamases [22-26]that degrade the $\beta$-lactam class of antibiotics. One strategy to combat this mechanism of drug resistance could be to provide a substance that is not itself antibacterial in the absence of any $\beta$-lactamase activity but becomes so in its presence. Noting that copper compounds can be significantly antibacterial [27-33], an embodiment of this strategy was recently proposed that exploited the ability of $\beta$-lactamases to activate a prochelator compound (PcephPT, phenylacetamido-cephem-pyrithione) to selectively release pyrithione (2-mercaptopyridine N-oxide) and thereby facilitate its known copper-dependent cytotoxicity [34,35]. In that work, we found that the combination of $\mathrm{Cu}$ (II) and pyrithione was indeed highly bacteriotoxic. This toxicity was manifested by the addition of PcephPT only in strains expressing $\mu$-lactamase activity that became tolerant to pyrithione and $\mathrm{Cu}(\mathrm{II})$ by the co-addition of the strong but membrane-impermeable $\mathrm{Cu}(\mathrm{I})$-sequestering 
agent, bathocuproinedisulfonic acid (BCS) [34]. The ability to release pyrithione selectively by $\mu$-lactamase-producing strains provides a compelling approach to pathogen-selective toxicity.

Pyrithione is a bidentate metal-binding agent that forms neutral, lipophilic metal complexes with divalent and trivalent metal ions [36]. These properties, and its ability to facilitate intracellular metal accumulation, categorise pyrithione as an ionophore, to distinguish its biological activity from metal chelators that sequester or deplete cellular metals [37]. The antimicrobial activity of pyrithione, even in its complexed form with $\mathrm{Zn}(\mathrm{II})$, is associated with its copper ionophore activity [34,35,38-40]. While it is often assumed that metal ionophores diffuse passively across lipid membranes to release intracellular metals, there is no direct evidence to support this mechanism. On the contrary, early reports presumed the need for mediated membrane transport for pyrithione, given its antibacterial efficacy and its low oleyl alcohol:water partition coefficient of 1.07 at $20^{\circ} \mathrm{C}, \mathrm{pH} 7.3$ [41].

Since the uptake and efflux of small molecule drugs, including those that are cytotoxic [42,43], requires the intercession of transport proteins [44-50], one question that arises is how pyrithione (and/or metals with which it interacts) might enter and exit the cytoplasm of target bacterial cells. The existence of the Keio collection of knockout strains of E. coli $[51,52]$ (and their over-expression equivalents $[53,54]$ ) provides a convenient means to address this question. Thus, in recent work, and because flow cytometry provides a very convenient uptake assay [55], we have used high-throughput flow cytometry to assess the ability of individual transporters to transport fluorescent molecules [56-58]. We here use related genetic strategies to assess the contributions of various transporters to the pyrithione uptake and efflux in E. coli cells, indicating substantial roles for several. The metal ion effluxers, $\mathrm{ZntA}$ and CopA, were found to have significant roles in protecting the bacterial cell against pyrithione toxicity, while the membrane transporters, FepC and MetQ, emerged as potential mediators in pyrithione uptake. The work presented here redirects the assumed passive crossing of pyrithione (similar to the assumption for most small molecules) to a mediated transport across cell membranes.

\section{Results}

In order to screen the membrane protein subset of the E. coli Keio knockout collection, we first evaluated the inhibitory concentrations $\left(\mathrm{IC}_{50}\right)$ of pyrithione-in the presence of excess copper-against the reference strain of E. coli, BW25113. The $\mathrm{IC}_{50}$ value for pyrithione in complex media (Lysogeny Broth (LB)) had a mean of some $6 \mu \mathrm{M}$ (Table 1), which decreased approximately ten-fold when the concentration of $\mathrm{CuCl}_{2}$ increased to $10 \mu \mathrm{M}$ and higher (Table 1). Although LB is expected to have baseline levels of copper present, the added metal ion clearly sensitised E. coli to the pharmacological actions of pyrithione, consistent with prior studies [34].

Table 1. Pyrithione inhibitory concentrations for the Keio collection E. coli reference strain, BW25113. Cells growing in complex media (LB) were subjected to varying pyrithione concentrations in the presence of incremental concentrations of $\mathrm{CuCl}_{2}$. Inhibitory concentrations as $\mathrm{IC}_{50}$ values are shown as the mean and standard deviation of four replicates.

\begin{tabular}{ccc}
\hline Media & $\mathbf{C u C l}_{\mathbf{2}}(\boldsymbol{\mu M})$ & $\mathbf{I C}_{\mathbf{5 0}}(\boldsymbol{\mu M})$ \\
\hline & 0 & $6.05 \pm 1.02$ \\
Lysogeny Broth (LB) & 5 & $5.22 \pm 0.95$ \\
& 10 & $0.78 \pm 0.25$ \\
& 20 & $0.81 \pm 0.28$ \\
\hline
\end{tabular}


2.1. Screening Membrane Protein Genes of the E. coli Keio Collection: Identification of Membrane Proteins Potentially Involved in the Pharmacological Actions of Pyrithione

In order to identify membrane proteins that affect pyrithione activity, growth rates in the exponential phase were recorded for the 532 Keio knockout strains lacking individual membrane proteins (Keio subset, Table S1) in the presence of a single, sublethal dose of $2 \mu \mathrm{M}$ pyrithione. The effect of pyrithione was quantitated as the ratio of the growth rate for each strain in the presence of this metal ionophore over the growth rate in its absence. As expected, the reference strain of E. coli, BW25113 (denoted here as "wild type" (WT)), showed a growth rate ratio with a mean close to 1.0, indicating that no differences in growth are detectable in the exposure versus the control cultures under these conditions (Table 2). The range of ratios for the Keio subset had an asymmetrical, right-skewed distribution with strains at the upper end growing at twice the rates in the presence of pyrithione (e.g., $f e p C$ and met $Q$, Figure 1). In the lower end of the distribution were strains that grew at half the rate with pyrithione (e.g., $\operatorname{cop} A$, Figure 1). The largest effect was observed in the strain lacking the $z n t A$ gene, with growth rates reduced approximately ten-fold when in the presence of sublethal concentrations of pyrithione (Figure 1).

Table 2. Growth rate ratios of the top and bottom ten hits from the subset of the Keio gene knockout collection exposed to pyrithione. E. coli reference strain BW25113 (WT) divides the knockout $(\mathrm{KO})$ strains presenting ratios of growth rates above and below the units. All strains were cultured in parallel in LB with or without $2 \mu \mathrm{M}$ pyrithione. Full list available in Table S1.

\begin{tabular}{cccc}
\hline Strain (KO) & \multicolumn{2}{c}{ Growth Rate Ratio } & Gene Annotation \\
\hline Mean & SD & L-methionine/D-methionine ABC transporter \\
membrane anchored binding protein
\end{tabular}




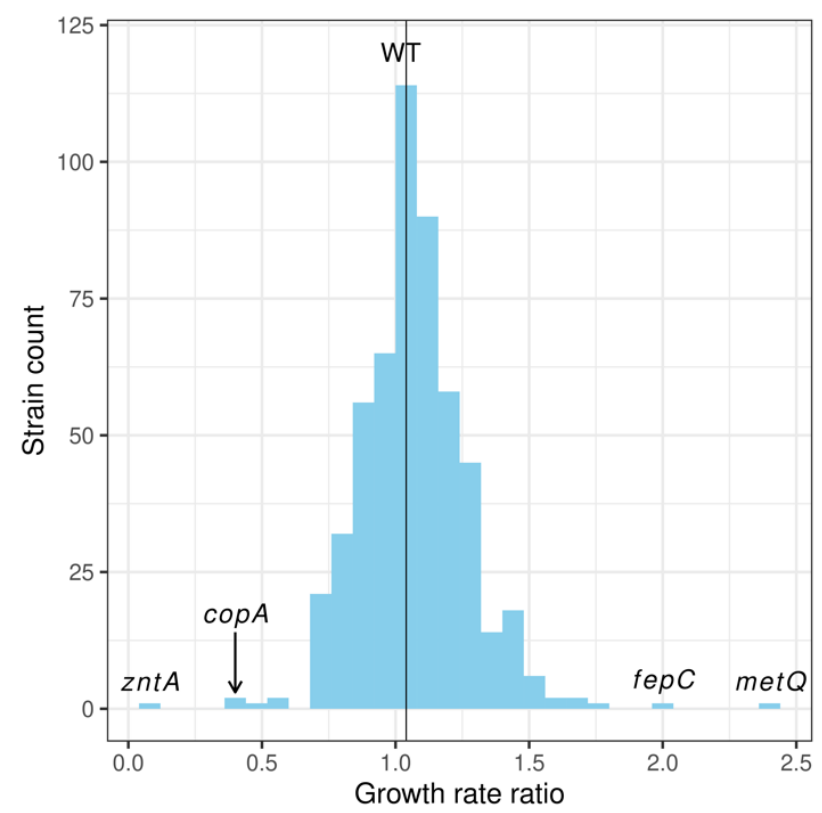

Figure 1. Distribution of bacterial growth in the presence of $2 \mu \mathrm{M}$ pyrithione. The Keio collection subset (532 knockout strains for gene encoding membrane proteins) was exposed to pyrithione and their growth compared against the unexposed samples and these ratios are represented in the abscissa. The reference strain (WT) with a mean ratio of 1.04 occupies the bin that contains the highest count of strains. The following four boundary knockout strains selected here are further denoted by the location of their growth rate ratios of exposed over unexposed: $z n t A, \operatorname{cop} A, f e p C$, and metQ.

2.2. Growth Kinetics of Knockout and Overexpression Strains for metQ, fepC, $\operatorname{cop} A$, and zntA Genes at Variable Concentrations of Pyrithione Expanded on the Observations from the Initial Knockout Library Screening

To gain more insight into the roles of the four major hits from the Keio screen with a single dose of pyrithione $(2 \mu \mathrm{M})$, the growth of the $\Delta \operatorname{cop} A, \Delta z n t A, \Delta m e t Q$, and $\Delta f e p C$ strains was next measured at the following incremental concentrations of pyrithione: 0,3 , 6,12 , and $25 \mu \mathrm{M}$. In addition to the knock-out strains, the over-expression (Aska) strains of these four genes were also challenged with increasing pyrithione and monitored for growth over time.

As observed in the initial screening experiment, the knockouts of $\operatorname{cop} A$ and $z n t A$ sensitised the cells to growth inhibition by pyrithione (Figures $2 c$ and $3 c$ ). The lack of $\operatorname{cop} A$ had a reduced growth (half of that of the reference strain) at low concentrations of pyrithione with total inhibition at the higher concentrations tested (12 and $25 \mu \mathrm{M})$ (Figure 2c). The absence of $z n t A$ resulted in even more severe growth inhibition, with cell growth halted from the lowest concentration tested (3 $\mu \mathrm{M})$ (Figure 3c). 
a

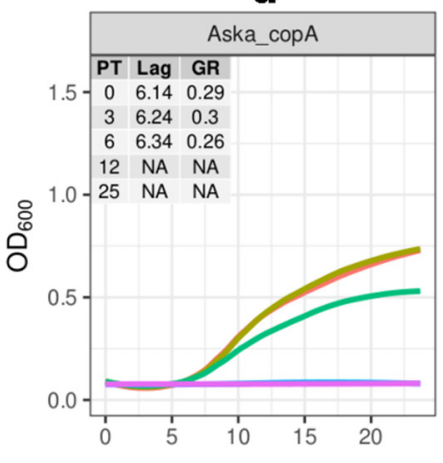

b

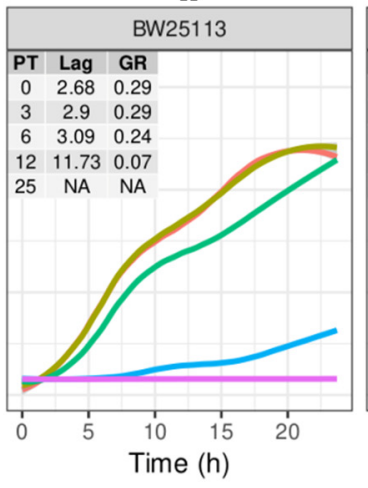

C

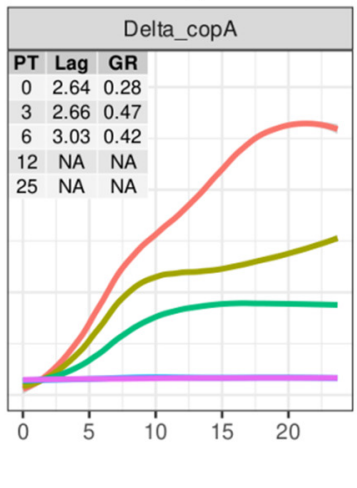

Pyrithione $[\mu \mathrm{M}]=0=3=6=12=25$

Figure 2. Effects of $\operatorname{cop} A$ on the sensitivity of E. coli to pyrithione. Growth $\left(\mathrm{OD}_{600}\right)$ at incremental concentrations of pyrithione in complex media (LB) of the (a) Aska clone carrying episomal copies of copA (Aska_copA), (b) the reference strain BW25113, and (c) the copA knockout strain (Delta_copA). Insets: PT: concentration of pyrithione in micromolar $(\mu \mathrm{M})$, Lag: length of lag phase in hours, GR: growth rate fitted from optical densities of the cultures in exponential phases. The colour coded lines represent the fitted data with the parametric non-linear method of least squares. NA (non-applicable): data below detection limit.

a

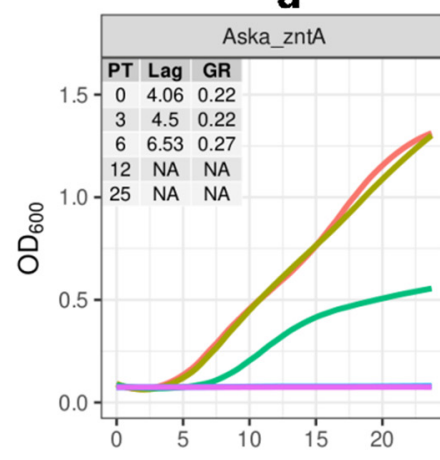

b

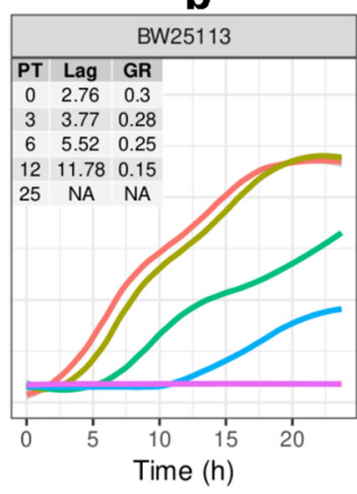

C

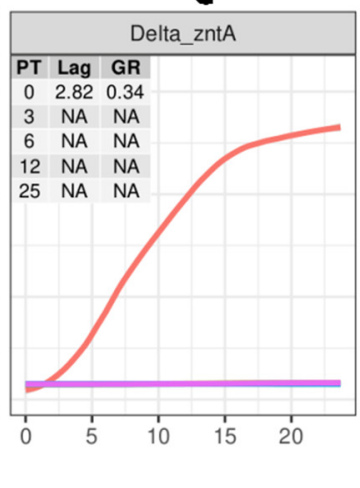

Pyrithione $[\mu \mathrm{M}]=0=3=6=12=25$

Figure 3. Effects of $z \boldsymbol{n t A}$ in the sensitivity of $\boldsymbol{E}$. coli to pyrithione. Growth $\left(\mathrm{OD}_{600}\right)$ at incremental concentrations of pyrithione in complex media (LB) of the (a) Aska clone carrying episomal copies of zntA (Aska_zntA), (b) the reference strain BW25113, and (c) the zntA knockout strain (Delta_zntA). Insets: PT: concentration of pyrithione in micromolar $(\mu \mathrm{M})$, Lag: length of lag phase in hours, GR: growth rate fitted from optical densities of the cultures in exponential phases. The colour coded lines represent the fitted data with the parametric non-linear method of least squares. NA (non-applicable): data below detection limit.

Overexpressing copA (Aska_copA) was visibly detrimental, with the duration of its lag phase being double that of the reference strain (Figure 2a). The impaired growth of Aska_copA was observed throughout $24 \mathrm{~h}$ (Figure 2a). Under the presence of pyrithione, Aska_copA had growth trends proportionally similar to that of the control for the initial concentrations of pyrithione. From $12 \mu \mathrm{M}$ pyrithione, Aska_copA did not grow. The overexpression of zntA (Aska_zntA) was also detrimental for growth compared to the parental strain (Figure 3a), although not as severely as Aska_copA. In the presence of pyrithione, the Aska_zntA growth was slightly impaired compared to the parental strain, but noticeably more resistant to pyrithione compared to the $z$ nt $A$ knockout (Figure $3 \mathrm{c}$ ). 
The growth of the knockout strains for the ABC transporters MetQ and FepC in the absence of pyrithione was comparable to the parental strain in both the lag phase and the growth rate (Figures $4 \mathrm{c}$ and $5 \mathrm{c}$ ). The growth at the sublethal concentration of $3 \mu \mathrm{M}$ pyrithione showed $\triangle m e t Q$ and $\triangle f e p C$ growing at equivalent levels with the absence of pyrithione, but not the higher levels that were observed for these strains in the large set screening (Table 2). We attribute that dissimilar behaviour to different conditions of nutrient circulation and partial oxygen pressures present in the wells of 384-well plates versus those conditions of much larger containers used for individual cultures when dealing with a discrete number of strains (i.e., only the reference strain plus $\Delta m e t Q, \Delta f e p C, \Delta \operatorname{cop} A$ and $\Delta z n t A)$. Nonetheless, the growth of $\Delta f e p C$ at higher $(\geq 6 \mu \mathrm{M})$ concentrations of pyrithione did supersede that of the parental strain (Figure $5 c$ ).

a


b

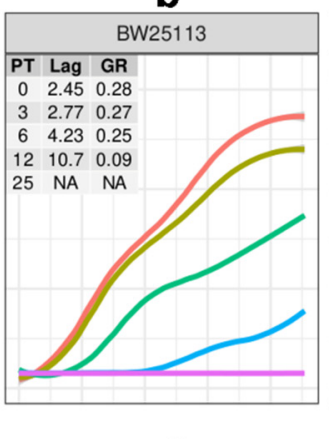

e

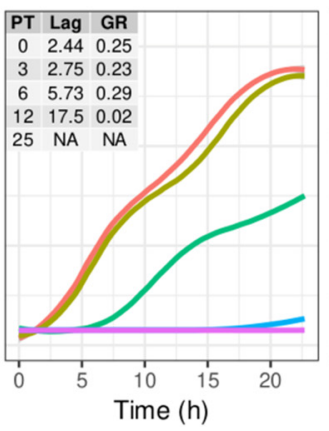

C



$\mathbf{f}$



Pyrithione $[\mu \mathrm{M}]=0=3=6=12=25$

Figure 4. Effects of MetQ in the sensitivity of E. coli to pyrithionine. (a-c) Growth $\left(\mathrm{OD}_{600}\right)$ at incremental concentrations of pyrithione in complex media (LB) of the Aska strain carrying an episomal copy of metQ (Aska_metQ) (a), the reference strain E. coli BW25113 (b); and the Keio strain of the met $Q$ knockout (Delta_metQ) (c). (d-f) As above with the addition of methionine at $3 \mathrm{mM}$ final concentration. Insets: PT: concentration of pyrithione in micromolar $(\mu \mathrm{M})$, Lag: length of lag phase in hours, GR: growth rates fitted from optical densities of the cultures in exponential phases with the parametric non-linear method of least squares. The colour coded lines represent the fitted data for cultures under the given concentrations of pyrithione in micromolar $(\mu \mathrm{M})$ units. NA (non-applicable): data below detection limit. 
a

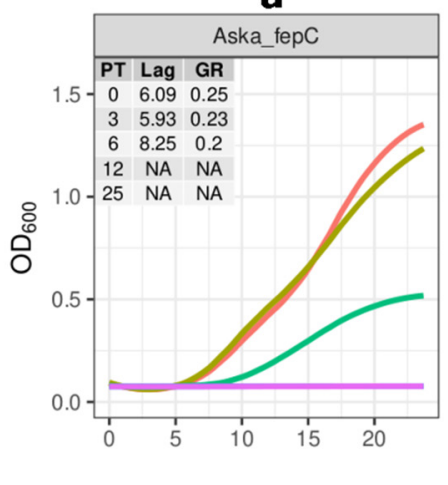

b

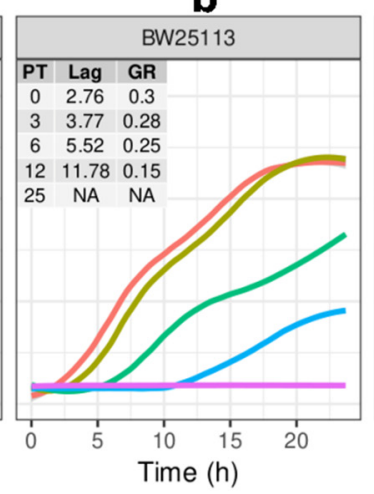

C



Pyrithione $[\mu \mathrm{M}]=0=3=6=12=25$

Figure 5. Effects of $f e p C$ in the sensitivity of $E$. coli to pyrithione. Growth $\left(\mathrm{OD}_{600}\right)$ at incremental concentrations of pyrithione in complex media (LB) of the (a) Aska clone carrying episomal copies of fepC (Aska_fepC), (b) the reference strain BW25113, and (c) the fepC knockout strain (Delta_fepC). Insets: PT: concentration of pyrithione in micromolar $(\mu \mathrm{M})$, Lag: length of lag phase in hours, GR: growth rate fitted from optical densities of the cultures in exponential phases. The colour coded lines represent the fitted data with the parametric non-linear method of least squares. NA (non-applicable): data below detection limit.

The expression of multiple copies of the gene encoding for MetQ (Aska_metQ) impaired E. coli growth, with approximately two-fold longer lag phases in complex media in comparison to the reference strain BW25113, which contains only the chromosomal copy of the same gene (Figure 4a). Under incremental concentrations of pyrithione, the overexpression of met $Q$ consistently displayed longer lag times and lower growth rates in the exponential phase compared to the equivalent in the reference strain. The cell growth was then assessed in media with pyrithione and MetQ's natural substrate, methionine, in order to discriminate MetQ-mediated pyrithione effects from confounding effects of the impaired growth fitness brought by the overexpression of MetQ. In complex media that had excess methionine, MetQ overexpression exacerbated sensitivity to pyrithione (i.e., three-fold longer lag phase with $6 \mu \mathrm{M}$ pyrithione compared to two-fold in the control strain, Figure 4). The growth rates in exponential phases were again consistently lower in the strain expressing high copies of met $Q$ than in the reference strain.

The overexpression of fepC (Aska_fepC) also caused an increased lag phase by approximately two-fold in comparison to the reference strain (Figure 5a). This effect was consistently observed through incremental concentrations of pyrithione until the growth for this strain was halted at $12 \mu \mathrm{M}$ pyrithione. The increased susceptibility of the Aska_fepC and Aska_metQ strains supports the notion that these transporters could be a pathway by which pyrithione accesses the cytosol.

\subsection{Effects of the Gene Knockouts on the Minimum Inhibitory Concentrations of Pyrithione in the Presence and Absence of Relevant Metals}

Given the notable metal involvement for three of the four genes identified in our knock-out hits, we assessed the minimal inhibitory concentration (MIC) of pyrithione in the absence and presence of supplemental $\mathrm{Cu}(\mathrm{II}), \mathrm{Zn}$ (II), and $\mathrm{Fe}(\mathrm{III})$, as well as the membrane impermeable $\mathrm{Cu}(\mathrm{I})$-sequestering agent, $\mathrm{BCS}$. The MICs of pyrithione alone were lowest for $\Delta z n t A(2.2 \mu \mathrm{M})$ and $\Delta \operatorname{cop} A(8.8 \mu \mathrm{M})$, compared to the others at $17.5 \mu \mathrm{M}$ (Table 3 and Figure 6a). Adding Cu did not shift the MIC for WT, $\Delta$ metQ, or $\Delta f e p C$, but did lower it for $\triangle \operatorname{cop} A$ and slightly increased it for $\Delta z n t A$. Adding $\mathrm{Zn}$ had the opposite effect, by decreasing the MIC of $\triangle z n t A$ but increasing it for $\triangle \operatorname{cop} A$. The other strains were mostly unaffected by $\mathrm{Zn}$, although $\triangle$ met $Q$ did result in an MIC lower by one dilution factor (Table 3). Adding Fe, on the other hand, had no effect on the MIC of any of the strains. 
Table 3. Minimum inhibitory concentrations (MICs) of pyrithione (PT) against E. coli BW25113 and knockout strains in the presence of metals ${ }^{a}$.

\begin{tabular}{cccccc}
\hline Conditions & BW25113 & metQ & fepC & copA & zntA \\
\hline PT alone & 17.5 & 17.5 & 17.5 & 8.8 & 2.2 \\
PT and 10 $\mu \mathrm{M} \mathrm{Cu}$ & 17.5 & 17.5 & 17.5 & 2.2 & 8.8 \\
PT and 10 $\mu \mathrm{M} \mathrm{Fe}$ & 17.5 & 17.5 & 17.5 & 8.8 & 2.2 \\
PT and 10 $\mu \mathrm{M} \mathrm{Zn}$ & 17.5 & 8.8 & 17.5 & 8.8 & 1.1 \\
PT and 1.92 $\mathbf{m M ~ B C S}$ & $>140$ & $>140$ & $>140$ & $>140$ & 140 \\
PT and 1.92 $\mathbf{~ m M ~ B C S ~ a n d ~ 1 0 ~} \mu \mathrm{M} \mathrm{Zn}$ & $>140$ & $>140$ & 140 & $>140$ & 17.5 \\
\hline
\end{tabular}
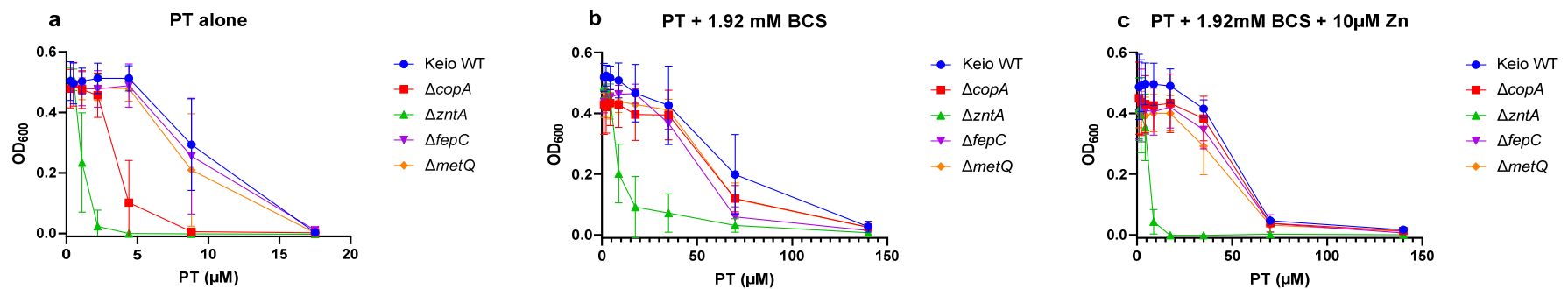

Figure 6. Growth under incremental concentrations of pyrithione (PT). Growth $\left(\mathrm{OD}_{600}\right)$ of E. coli K-12 BW25113 (Keio WT) and the Keio knockout strains $\Delta \operatorname{cop} A, \Delta z n t A, \Delta f e p C$, and $\Delta m e t Q$, compared across the relevant concentrations of PT alone (a), or in combination with $1.92 \mathrm{mM}$ BCS (b), or in combination with $1.92 \mathrm{mM} \mathrm{BCS}$ and $10 \mu \mathrm{M} \mathrm{ZnCl}{ }_{2}(\mathbf{c})$.

The presence of BCS rescued the growth of all the strains tested, as indicated by the increase in the MIC at or above $140 \mu \mathrm{M}$ pyrithione (Table 3 and Figure $6 \mathrm{~b}$ ). Interestingly, BCS had a diminished effect on the $\triangle z n t A$ strain compared to the others. Although it caused the MIC value to increase from 2 to $140 \mu \mathrm{M}$, the growth of the $\Delta z n t A$ strain was significantly lower than the other strains starting at all concentrations of pyrithione (Figure 6b). As BCS is selective for $\mathrm{Cu}(\mathrm{I})$ and is not expected to directly affect $\mathrm{Zn}$ speciation in these experiments, the abrogation of pyrithione's activity by BCS points to a Cu-dependent mechanism of toxicity. The weaker effect of BCS on the $\triangle z n t A$ strain, however, suggests a contributing role for $\mathrm{Zn}$ as well. To test this idea, we added supplemental $\mathrm{Zn}$ in combination with BCS and pyrithione. This combination had a profound effect only on the $\triangle z n t A$ strain, with the MIC value that decreased from the BCS-induced 140 to $17.5 \mu \mathrm{M}$ PT upon the addition of Zn (Table 3 and Figure 6c).

As the MIC values alone are not an indication of cell killing, the bactericidal effects of pyrithione were measured for all five strains in the presence of either $\mathrm{Cu}, \mathrm{Fe}$, or $\mathrm{Zn}$, as indicated in Figure 7. Pyrithione alone is not bactericidal, although the absence of the ZntA transporter was more sensitive than any of the other strains (Figure 7). The presence of excess copper made pyrithione cytocidal to all five strains. In agreement with the growth data (Figure 4), the absence of MetQ showed some level of protection in some of the samples (Figure 7). When the cells were treated with zinc or iron in addition to pyrithione, $\triangle z n t A$ had the most samples that showed partial cidality. The presence of BCS, though, seemed to decrease the cytocidal effects of pyrithione for $\triangle z n t A$. Taken together, these data reinforce the notion that $\mathrm{Cu}$ is the strongest mediator of pyrithione toxicity, with $\mathrm{Zn}$ perhaps playing a supporting role. 


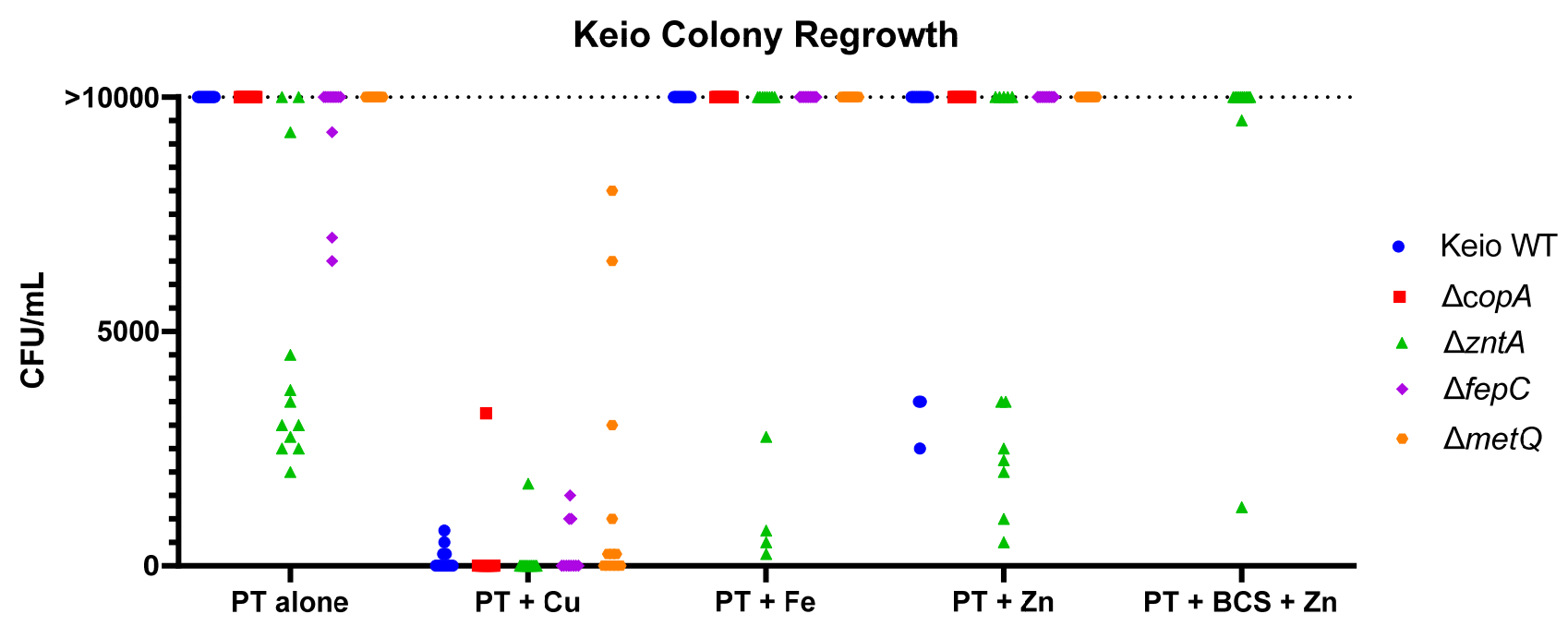

Figure 7. Ability of PT to kill E. coli K-12 BW25113 (Keio WT) and the knockout strains, $\Delta \operatorname{cop} A, \Delta z n t A, \Delta f e p C$, and $\Delta m e t Q$. Bacteria treated for $20 \mathrm{~h}$ with the minimum inhibitory concentration of pyrithione for that condition (Table 3) with or without $10 \mu \mathrm{M} \mathrm{Cu}, \mathrm{Fe}, \mathrm{Zn}$, or $1.92 \mathrm{mM} \mathrm{BCS}$, were plated on fresh LB agar and incubated at $37^{\circ} \mathrm{C}$ for $24 \mathrm{~h}$ prior to colony enumeration. Each point on the graph represents an individual replicate. Number of viable cells (measured as CFU/mL) at $0 \mathrm{~h}$ for the untreated bacteria samples were as follows: Keio WT $=1.7 \times 10^{6}, \Delta \operatorname{cop} A=1.3 \times 10^{6}, \Delta z n t A=1.4 \times 10^{6}$, $\Delta f e p C=0.7 \times 10^{6}$, and $\Delta m e t Q=2.0 \times 10^{6}$.

2.4. Levels of Cell-Associated Metals in the Absence of Membrane Transporters CopA, ZntA, FepC, and MetQ

In order to assess the relative effects of pyrithione on the total cellular metal content of our strains of interest under conditions where the cells are viable, we selected treatment conditions below the MIC values for each strain: $\Delta c o p A$ and $\Delta z n t A$ were treated for $15 \mathrm{~min}$ with $0.5 \mu \mathrm{M}$ pyrithione in the absence or presence of supplemental $10 \mu \mathrm{M} \mathrm{Cu}$ (II), $\mathrm{Zn}$ (II), or $\mathrm{Fe}(\mathrm{III})$ added to the broth, while $\Delta f e p C$ and $\Delta$ met $Q$ were treated similarly, but with $4 \mu \mathrm{M}$ pyrithione. The copper levels associated with the cells (membranous compartment and/or intracellular) were generally higher in the $\Delta \operatorname{cop} A$ and $\Delta z n t A$ knockouts compared to wild type across all the treatments, with the most notable increase seen in the combination treatment of pyrithione with added $\mathrm{Cu}$ (Figure 8a). The total zinc levels were also generally higher on average for $\Delta \operatorname{cop} A$ and $\Delta z n t A$ compared to WT, although the variability in the data makes these changes hard to distinguish (Figure $8 b$ ). Notable, however, is the observation that the combination of PT and Zn does not lead to Zn hyperaccumulation in the transporter knockouts compared to WT (Figure 8b), in direct contrast to the trend observed for $\mathrm{Cu}$. These data show that the increased sensitivity of the $\triangle z n t A$ strain is not related to an accumulation of $\mathrm{Zn}$, but rather suggest that $z n t A$ contributes to $\mathrm{Cu}$ clearance under pyrithione-induced stress. This conclusion is consistent with the sensitivity of the MIC of this strain to BCS (Table 3). Fe levels in $\Delta \operatorname{cop} A$ and $\Delta z n t A$ were not noticeably affected by pyrithione under the tested conditions (Figure 8c), consistent with expectations based on known substrates for these transporters, which do not include Fe. 

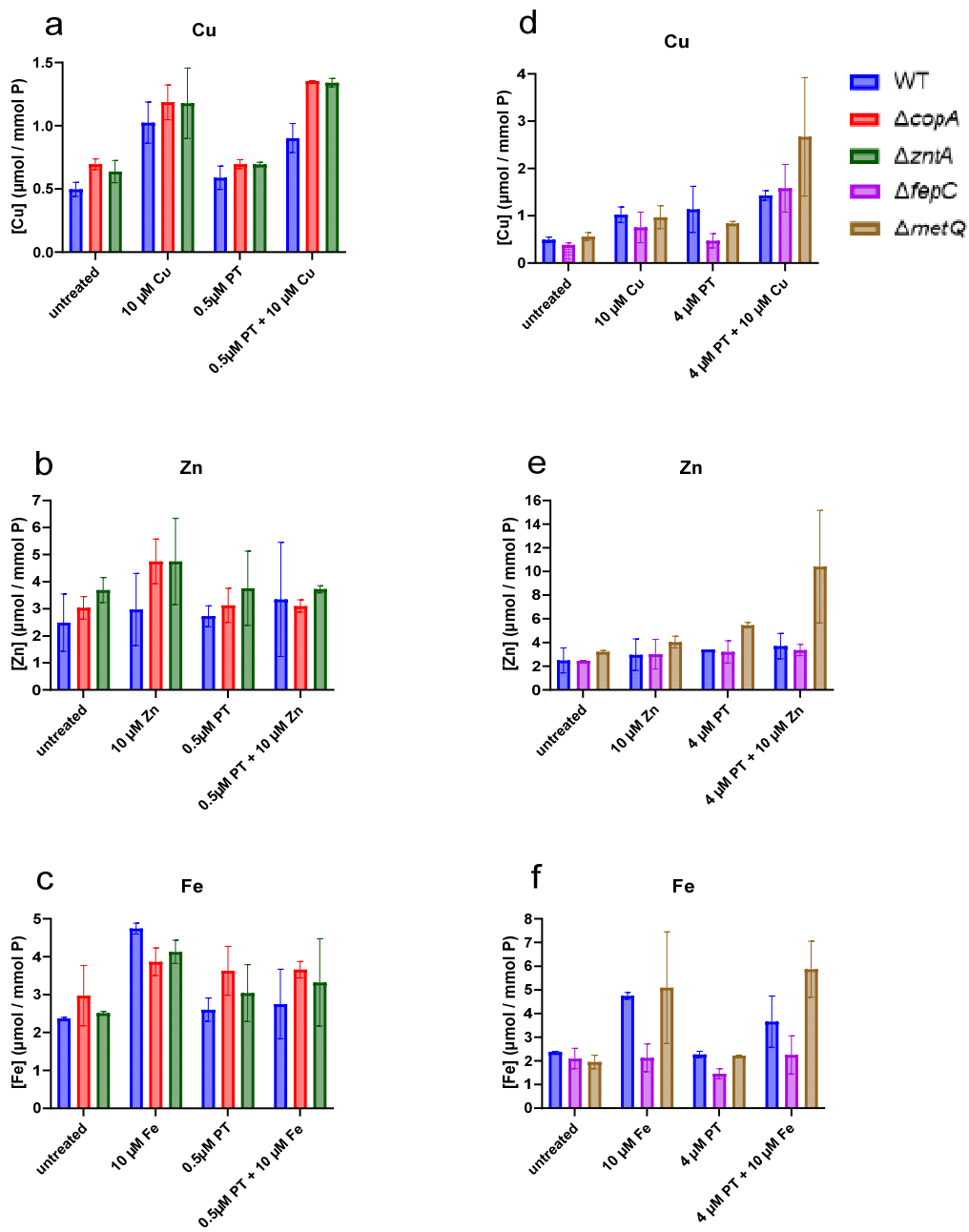

Figure 8. Cell-associated $\mathrm{Cu}, \mathrm{Zn}$, and Fe in wild-type (WT) E. coli K-12 BW25113 and the Keio knockout strains. (a) Cell-associated copper, (b) zinc, and (c) iron in the WT and knockout strains $\triangle \operatorname{cop} A$ and $\Delta z n t A$. (d) Cell-associated copper, (e) zinc, and (f) iron in WT and knockout strains $\Delta f e p C$ and $\triangle m e t Q$. Metal content was measured using ICP-MS as detailed in Materials and Methods and normalised to phosphorus for each sample. Data are shown as the average of two biological replicates taken with three technical replicates each, with the range indicated by the error bars.

The comparison of the $\triangle f e p C$ and $\triangle m e t Q$ strains with wild type reveals interesting metal-dependent responses. The total metal levels increased noticeably for $\Delta m e t Q$ compared to the WT cells subjected to the same combination treatment of pyrithione and $\mathrm{Cu}, \mathrm{Zn}$, or Fe (Figure 8d-f). In contrast, the levels of $\mathrm{Cu}$ and $\mathrm{Zn}$ were unchanged in $\triangle$ fep $\mathrm{C}$ compared to WT when these metals were co-administered with pyrithione (Figure $6 \mathrm{~d}, \mathrm{e}$ ), whereas the Fe levels decreased compared to WT for that condition (Figure 6f). The consistent increase in $\mathrm{Cu}, \mathrm{Zn}$, and Fe levels when each metal was co-administered with pyrithione suggests something unique about the pyrithione-enabled uptake of these metals when methionine transport is disabled by $\Delta m e t Q$. Although the data do not provide direct evidence, it is interesting to speculate a potential route for pyrithione-metal complexes via the enterobactin uptake pathway. Notably, when that pathway is prevented by $\triangle f e p C$, the total $\mathrm{Cu}, \mathrm{Zn}$, and Fe levels are not elevated, compared to untreated or metal-only WT controls. These data, therefore, suggest a potential model in which pyrithione is preferentially taken up as an uncomplexed monomer by the methionine transport machinery, while metal complexes preferentially co-opt the siderophore pathway, which would thereby lead to increased cellular metal loads. 


\section{Discussion}

Using genetically modified strains of the Gram-negative E. coli, we have presented here a discrete number of membrane transporters likely involved in the facilitated transit in and out of the cell of pyrithione and its associated metal cations, most relevantly $\mathrm{Cu}$ and $\mathrm{Zn}$. The properties of pyrithione as a metal ionophore are necessary for its cytotoxicity, as originally reported [59], at concentrations similar to those reported here for E. coli, particularly in the presence of added $\mathrm{Cu}$ (Table 3 and Figure 7, WT strain). At millimolar concentrations, much higher than used here, pyrithione has been shown to inhibit certain membrane transport systems, depolarise the cell membrane in microorganisms, as well as reduce cellular protein synthesis and ATP levels $[39,60]$. The finding that the $\triangle a t p A$ strain was hypersensitive to low concentrations of pyrithione (Table 2) is consistent with these prior observations. Furthermore, several knockout strains lacking sugar transporters were identified here as having growth impaired by pyrithione ( $f u c P$, malF, $x y l E$, Table 2). Combined, the susceptibility of these knockout strains points to the metabolic and respiratory strain experienced by cells as a consequence of pyrithione exposure. Other hits (Table 2 and Table S1) are represented by "y-genes" (genes of unknown function) that still represent some $35 \%$ of the E. coli gene complement. The behaviour of the top four knockouts (metQ, $f e p C, \operatorname{cop} A$, and $z n t A)$ merited further investigation.

The increased cytotoxicity of pyrithione with added $\mathrm{Cu}$ suggests that $\mathrm{Cu}$ either exacerbates pyrithione's direct impairment of these respiratory processes, or $\mathrm{Cu}$ could be the direct cause. Evidence for $\mathrm{Cu}^{\prime}$ s toxic effects is abundant, and its direct impact on the proteins required for metabolism, respiration, and protein synthesis is steadily emerging, as revealed, for example, by a study in Staphylococcus aureus that found that Cu stress targets proteins involved in central carbon metabolism [61]. Additionally, a recent proteomics study from one of us used protein folding stability measurements to identify protein hits of pyrithione in combination with $\mathrm{Cu}$ [33]. In that study, we found a number of protein hits involved in glycolysis, the citric acid cycle, and protein biosynthesis that were distinctly driven by the $\mathrm{Cu}$ delivered to the cell by pyrithione [33]. In the context of the current results identifying the $\triangle \operatorname{cop} A$ knockout strain as highly sensitive to pyrithione, a picture emerges that pyrithione's mechanism of action is directly linked to its facilitation of $\mathrm{Cu}$ gaining unregulated access to the cytoplasm of E. coli, consistent with its activity in yeast [62].

Copper ions are required in low concentrations for multiple metalloenzymes (e.g., copper oxidases, amine oxidases, cytochrome oxidases, $\mathrm{Cu}, \mathrm{Zn}$-SOD), which in E. coli are found exclusively in the cell envelope. Bacteria sustain these low levels of the otherwise toxic free cellular copper with vectorial transmembrane transport and compartmental trafficking via cytoplasmic and periplasmic chaperones, avoiding the presence of free, uncomplexed copper $[63,64]$. Although the entry route for copper is unclear in bacteria, its efflux relies on metal exporters such as CopA, a P-type ATPase that sits on the inner membrane and actively clears the cytosol of $\mathrm{Cu}(\mathrm{I})$ by pumping it into the periplasm, where it can subsequently be oxidised to the less damaging $\mathrm{Cu}$ (II) by $\mathrm{CueO}$, incorporated into cuproenzymes, or effluxed from the cell by the Cus system [65-68]. CopA is a $\mathrm{Cu}(\mathrm{I})$ exporter specifically induced by copper or silver $[67,68]$. CopA interacts with soluble chaperones on either side of the cytoplasmic membrane as part of the ion permeation path that also includes the outer membrane CusCBA system for the efflux of copper to the extracellular milieu [69-71].

The absence of CopA decreases the cytoplasmic efflux efficiency, thereby leaving the cytoplasm susceptible to the toxicity of $\mathrm{Cu}(\mathrm{I})$ [70]. High concentrations of $\mathrm{Cu}$ can induce unregulated membrane permeability and impair proton-coupled membrane transport, which increases the lag growth phase duration and reduces the rate of exponential growth [72], in line with our observations on the effect of pyrithione on the $\triangle$ copA knockout strain (Figures 1 and 2c, Table 3). The absence of $\operatorname{cop} A$ increased the concentrations of cell-associated $\mathrm{Cu}$ (Figure 8a) and the cytotoxicity of pyrithione diminished when $\mathrm{Cu}$ was sequestered by the membrane-impermeable $\mathrm{Cu}(\mathrm{I})$ chelator BCS (Figures 6 and 7). Overexpressing CopA did not overcome the toxicity of pyrithione as we might have expected 
given its role (Figure 2a). However, the overexpression of membrane transporters is known to be mostly deleterious $[73,74]$. Pyrithione itself has been shown to induce the overexpression of CopA and CueO [33]. It could be that excess CopA, as provided genetically in the Aska-CopA strain, might have impaired the homeostatic machinery to such a degree that the exposure to pyrithione only worsened downstream cytotoxicity.

While the data collected in this study consistently point to a primary role for $\mathrm{Cu}$ toxicity in the mechanisms of pyrithione exposure, the fact that the $\Delta z n t A$ knockout strain provided the strongest growth-impaired phenotype raises the question of $\mathrm{Zn}$ 's contribution to pyrithione activity (Figures 1 and 3c, Table 2). The most conclusive evidence for a direct role for $\mathrm{Zn}$ was observed by the re-sensitisation of $\Delta z n t A$ to pyrithione when $\mathrm{Zn}$ was added to the BCS-treated cells (Table 2, Figure 6). BCS treatment creates a functional Cu deficiency that abrogated pyrithione activity in the other strains tested, with the MICs increasing to $140 \mu \mathrm{M}$ or higher. In contrast, BCS did not recover $\Delta z n t A$ growth to the same extent (Figure $6 \mathrm{~b}$ ), and this strain was re-sensitised when $\mathrm{Zn}$ was added in combination with pyrithione and BCS (Figure 6c). ZntA is a Zn(II) and cadmium(II) P-type ATPase [75,76], with Cd(II) being its most effective inducer [77-79]. Its transport activity for Cd(II) or other non-native but known heavy metal substrates such as $\mathrm{Pb}$ (II) or $\mathrm{Hg}$ (II) is not expected to be operative under the conditions of these experiments, although it is possible that ZntA is contributing directly to $\mathrm{Cu}$ clearance. It is also possible that $\mathrm{Cu}$ stress could cause the release of internal $\mathrm{Zn}$ stores that become problematic when $\mathrm{ZntA}$ is missing. Interestingly, ZntA was one of the strongest over-expression and protein-stability hits from our previous proteomics study [33]. The analysis of these data suggested that pyrithione, not $\mathrm{Cu}$, drove the increase in protein stability. An increase in protein stability is induced by ligand binding, which, in this case, could be driven by a metal binding to ZntA, or alternatively, an adduct with pyrithione itself, either as a ternary complex of transporter-metal-pyrithione or as a covalent modification such as disulfide bond formation between pyrithione and one of the many cysteines of ZntA (and CopA).

The identification of CopA and ZntA as critical components of the resistance mechanism against pyrithione-induced toxicity is consistent with the functional annotation of pyrithione as an ionophore that facilitates metal hyperaccumulation in cells. These transporters, however, do not address how pyrithione and its associated metals gain access to the cytoplasm to induce toxicity. This study identified MetQ and FepC as likely candidates, although it is important to note that these are not expected to be exclusive routes for pyrithione uptake, as evidenced by the number of other gene knockouts that showed increased growth rate ratios with pyrithione (Table 1). Nevertheless, it is interesting to speculate whether MetQ and FepC facilitate the uptake of pyrithione as a monomer or as a metal complex.

The lipoprotein MetQ is the substrate binding protein for MetNI, the ATP Binding Cassette $(\mathrm{ABC})$ membrane transport system responsible for the high affinity import of methionine [80,81]. MetQ forms a stable complex with the rest of this transport system via an N-terminal lipidic modification [82]. The observation that the met $Q$ knock-out strain grew comparatively better in the presence of pyrithione suggests that the cells gained some growth advantage in the presence of this sulphur-containing molecule when the cells were deprived of their regular methionine-uptake system. The absence of $f e p C$ also provided a noticeable advantage under these conditions. FepC is the cytoplasmic membrane transporter that, together with a periplasmic protein $(\mathrm{FepB})$ and an outer membrane transporter (FepA), are the ABC membrane transport complex that facilitates siderophore-mediated iron uptake using the siderophore enterobactin [83]. The identification of a transporter involved in taking up a metal complex raises the question of whether the metal coordination complexes of pyrithione might co-opt this system to gain entry to the bacterial cytoplasm.

A number of other hits that decreased the growth rate ratio are involved in sugar transport $(f u c P, m a l F, x y l E)$ and energy storage $(\operatorname{atp} A)$ (Table 2). The susceptibility of these strains signals that pyrithione is causing strain on metabolic processes. Other hits (Table 2 and Table S1) are represented by "y-genes" (genes of unknown function) that still represent 
some $35 \%$ of the E. coli gene complement. The behaviour of the top four knockouts (metQ, $f e p C, \operatorname{cop} A$ and $z n t A$ ) merited further investigation.

The MetQ-mediated influx of methionine seemed to have increased the penetration of pyrithione (Figure 4d), which points to a co-transport mechanism for these two molecules. It is also possible that $\mathrm{Cu}(\mathrm{I})$ could highjack this uptake pathway by binding to pyrithione and/or the thioether group of methionine [64], a natural substrate of MetQ. Both scenarios, methionine and pyrithione co-transport by MetQ, and the affinity of MetQ for substrates that can form metal complexes, could explain the hyper-sensitivity to pyrithione in the presence of excess methionine in cells overexpressing met $Q$ (Figure $4 \mathrm{~d}$ ). Other transport systems might be involved in this methionine-dependent sensitivity to pyrithione since a similar but lesser effect was also seen in the reference strain and the knockout strain for $m e t Q$ (Figure 2e,f). The likely candidates would be expected to be in the strains that survived the exposure to sublethal pyrithione similarly or better than the reference strain (Table 2).

We also observed that the strain lacking met $Q$ had higher cell-associated $\mathrm{Cu}$ and $\mathrm{Zn}$ in the presence of pyrithione vs. the metal alone compared to the other strains included in this study (Figure 8d-f). Cell-associated $\mathrm{Cu}$ can exist in two oxidation states, $\mathrm{Cu}(\mathrm{I})$ and $\mathrm{Cu}(\mathrm{II})$, which are readily complexed by biological ligands. Cupric ion, $\mathrm{Cu}(\mathrm{II})$, can exist in the oxidising environment of the periplasm, while the more reactive cuprous ion, $\mathrm{Cu}(\mathrm{I})$, is the more likely form in the reducing environment of the cytoplasm [64]. The ICP-MS data collected here for total cell-associated metal levels do not distinguish the compartmental location or the oxidation state. The observation of augmented concentrations of cellassociated metals in met $Q$ knockout cells without seeing an increased susceptibility to pyrithione suggests that this extra metal load might be accumulating in the periplasm. The chelation of metals outside the cytoplasm by the accumulated pyrithione (e.g., in $m e t Q$ knockout cells) might not generate cytotoxicity. An alternative scenario is that MetQ transports pyrithione alone, with pyrithione-metal complexes entering via an alternate route, such as FepC. In this scenario, the absence of MetQ could increase the flux through those alternates, resulting in higher total metal levels.

As with met $Q$, the absence of $f e p C$ also provided a noticeable advantage under these conditions. FepC is the cytoplasmic membrane transporter that together with a periplasmic protein (FepB) and an outer membrane transporter (FepA) are the $\mathrm{ABC}$ membrane transport complex that facilitates siderophore-mediated iron uptake using the siderophore enterobactin [83]. The identification of a transporter involved in taking up a metal complex raises the question of whether metal coordination complexes of pyrithione might co-opt this system to gain entry to the bacterial cytoplasm. The overexpression of $f e p C$ sensitised E. coli to the growth inhibition caused by pyrithione, while its absence protected the cells to this effect, Figure $5 \mathrm{a}, \mathrm{c}$, respectively. The fepC knockout strain only presented cell-associated metal changes for iron. In the absence of fepC, the levels of iron were lower than the reference strain, and more visibly, they were also lower than the met $Q$ knockout strain (Figure 8f). Pyrithione seemed to have decreased further the level of iron in the fepC knockout. Altogether, this implies FepC transports pyrithione:iron complexes that, rather straightforwardly, follows its natural role as a transporter of iron complexes [83].

\section{Conclusions}

These findings further our understanding of the cellular activity of pyrithione. Our data are consistent with a model of pyrithione complexing $\mathrm{Cu}(\mathrm{II})$, then transporting and releasing the more reactive $\mathrm{Cu}(\mathrm{I})$ intracellularly. Our data suggest that this ionophore activity is mediated via membrane transport as opposed to passive diffusion. This mechanism was envisaged in the early characterisation of pyrithione's chemistry and biological toxicity in bacteria that indicated that the compound forms chelate complexes and exerts its action intracellularly following dissociation. A likely mediated membrane transport-reported here-for crossing was logically anticipated as " ... a third factor playing a part" [41]. Altogether, we envisage the flow of a metallodrug such as pyrithione that can chelate 
cations on either side of the plasma membrane and is transported in or out of the cell by host proteins with or without its metal cargo.

\section{Materials and Methods}

\subsection{Strains and Culture}

The E. coli Keio collection of gene knockout strains was provided by the National Institute of Genetics, Mishima, Shizuoka, Japan [51,52]. A subset of 532 strains from the Keio Collection whose cognate knockout genes are annotated as encoding for membrane proteins were selected for this study (Table S1). Individual knockout strains highlighted in this work are as follows: copA (F-, $\Delta$ (araD-araB)567, $\triangle$ lacZ4787(::rrnB-3), $\lambda$-, $\triangle$ copA767::kan, rph1, $\Delta$ (rhaD-rhaB)568, hsdR514); fepC (F-, $\Delta$ (araD-araB)567, $\Delta$ lacZ4787(::rrnB-3), $\triangle$ fepC726::kan, $\lambda-$, rph-1, $\Delta$ (rhaD-rhaB)568, hsdR514); metQ (F-, $\Delta$ (araD-araB)567, $\Delta$ lacZ4787(::rrnB-3), $\lambda$-, $\Delta$ metQ722::kan, rph-1, $\Delta$ (rhaD-rhaB)568, hsdR514); zntA (F-, $\Delta$ (araD-araB)567, $\Delta$ lacZ4787 (::rrnB-3), $\lambda-, r p h-1, \Delta z n t A 724:: k a n, \Delta(r h a D-r h a B) 568, h s d R 514)$. PCR was used to verify that we were given the correct strains. We also used strain overexpressing $\operatorname{cop} A$, fepC, and met $Q$, and $z n t A$ from the ASKA collection: E. coli K-12, strain AG1 [recA1 endA1 gyrA96 thi-1 hsdR17 ( $r \mathrm{~K}-m \mathrm{~K}+$ ) supE44 relA1] carrying recombinant constructs in the IPTG-inducible and multicopy plasmid pCA24N (CmR, lacIq). The induction with IPTG was optimised to $250 \mu \mathrm{M}$ for $3 \mathrm{~h}\left(37^{\circ} \mathrm{C}\right.$, shaking at $\left.200 \mathrm{rpm}\right)$ before the growth assays. The ASKA collection [53] was also provided by the National Institute of Genetics, Mishima, Shizuoka, Japan.

Pyrithione (2-mercaptopyridine N-oxide) was purchased from Sigma (Cat 188549) and stock solutions were prepared in dimethyl sulfoxide (DMSO). Bacterial cultures were routinely carried out in lysogeny broth (Merck LB 110285) [58]. Growth inhibitory concentrations $\left(\mathrm{IC}_{50}\right)$ for pyrithione in the E. coli Keio reference strain BW25113 were calculated from microtitration assays. Overnight cultures in LB were diluted 1 in 1000 in fresh LB. Fifty $\mu \mathrm{L}$ of two-fold dilutions of pyrithione were transferred to 96-well plates to which $50 \mu \mathrm{L}$ of fresh bacterial culture were added. Endpoint reads of the media turbidity at $600 \mathrm{~nm}\left(\mathrm{OD}_{600}\right)$ were taken after $24 \mathrm{~h}$ at $37^{\circ} \mathrm{C}$.

The pyrithione exposure growth assays for the Keio collection subset of 532 strains (Table S1) were carried out by replicating their glycerol stocks into 384-well plates with $50 \mu \mathrm{L}$ of LB containing $30 \mu \mathrm{g} / \mathrm{mL}$ of kanamycin. These sealed plates were incubated overnight at $37^{\circ} \mathrm{C}$. The overnight cultures were diluted 1 in 1000 in $50 \mu \mathrm{L}$ of fresh LB without kanamycin in polystyrene 384-well plates with a transparent bottom (Sigma M6936-40EA). These plates were sandwiched with plastic covers (CR1384, Enzyscreen) and incubated for $24 \mathrm{~h}$ at $37^{\circ} \mathrm{C}$ with $225 \mathrm{rpm}$ shaking in the Growth Profiler. Plates with pyrithione contained this compound at $2 \mu \mathrm{M}$ final concentration.

\subsection{Growth Profiling}

The Growth Profiler 960 (Enzyscreen, NL; http:/ / www.enzyscreen.com/growth profiler.htm, accessed on 16 June 2020) records the pixel density ( $G$ values) of photographs per well. This instrument estimates culture density using the changes in these camerabased measurements, in parallel, of up to ten 96-well plates by extrapolating $\mathrm{G}$ values into optical densities $\left(\mathrm{OD}_{600}\right)$ using strain and media-dependent standard curves [57]. Although 384-well plates are not the usual format used for the Growth Profiler, we observed that the $G$ values from image analyses provided sigmoidal curves over time that fitted into non-linear parametric regressions used here to calculate exponential growth rates. The growth of smaller number of strains was also measured by media turbidity $\left(\mathrm{OD}_{600}\right)$ in the plate reader BMG Clario plus (BMG).

The inhibitory concentrations of pyrithione that kills half of the bacteria population ( $\left.\mathrm{IC}_{50}\right)$ were calculated with the four-parameter logistic model as implemented in the R [84] and the package $d r c$ [85], following the guidelines for relative calculations according to the spread of the data [86]. The growth rates in the exponential phase of batch cultures were extracted from the curve fitting of cell growth with a parametric non-linear method 
(i.e., method of least squares). The lag times were calculated using a linear fitting of the log-transformed data $[87,88]$. Both approaches were carried out as implemented in the $\mathrm{R}$ package growthrates [89].

For the microdilution assays, the Keio knockout strains were grown for approximately $20 \mathrm{~h}$ on LB agar containing $50 \mu \mathrm{g} / \mathrm{mL}$ kanamycin. The wild type was grown for approximately $20 \mathrm{~h}$ on LB agar. One colony of the respective knockout strain was used to inoculate $2 \mathrm{~mL}$ of LB containing $50 \mu \mathrm{g} / \mathrm{mL}$ kanamycin. The wild type was inoculated into $2 \mathrm{~mL}$ of just LB. These were then incubated for $16-18 \mathrm{~h}$ at $37^{\circ} \mathrm{C}$ and $200 \mathrm{rpm}$. The overnight cultures were then diluted 1:500 in fresh LB and used as the working solution. Pyrithione was serially diluted 2-fold in LB to reach concentrations of $0-140 \mu \mathrm{M}$ and plated in a clearbottomed 96-well plate. The cell working solution was then treated with $10 \mu \mathrm{M} \mathrm{CuCl}_{2}$, $\mathrm{ZnCl}_{2}$, ferric ammonium citrate, and/or the copper(I) chelator bathocuproinedisulfonic acid (BCS) and added to the plates for a final dilution of 1:1000 and 100 $\mu \mathrm{L}$ per well. Wells containing media only, cell working solution only, and treated cell working solution only, were included to verify sterility and the effect of metals alone. Plates were incubated at $37^{\circ} \mathrm{C}$ and $200 \mathrm{rpm}$ for $20 \mathrm{~h}$. The plates were sealed with AeraSeal film (EXCEL Scientific) to minimise evaporation during incubation. Bacterial growth was determined by measuring the $\mathrm{OD}_{600}$ using the PerkinElmer Victor3 V multilabel plate reader at 0 and $20 \mathrm{~h}$. The $0-\mathrm{h}$ time point was subtracted from the 20-hour time point to remove the background. The minimum inhibitory concentration (MIC) was defined as the dilution at which no more growth occurred $(20 \mathrm{~h} \mathrm{OD} 600<0.010)$. Three biological replicates were performed, each with 3 technical replicates. MICs were measured after bacteria were incubated at $37^{\circ} \mathrm{C}$ and $200 \mathrm{rpm}$ in $\mathrm{LB}$ for $20 \mathrm{~h}$. Growth was assessed using $\mathrm{OD}_{600}$ measurements. The following PT concentrations were tested: $140,70,35,17.5,8.8,4.4,2.2,1.1$, and $0.5 \mu \mathrm{M}$. MICs within one dilution factor were not considered statistically significant. A minimum of 2 biological replicates were performed. Each biological replicate had a minimum of three technical replicates.

At the 20-h time point of the microdilutions above, $4 \mu \mathrm{L}$ of each of the MIC-treated cultures were spotted on fresh LB agar and allowed to dry. These were then incubated at $37^{\circ} \mathrm{C}$ and $200 \mathrm{rpm}$ for $24 \mathrm{~h}$. The number of colonies grown were then counted.

\subsection{Measurement of Cell Associated Copper}

Intracellular metal concentrations were determined using inductively coupled plasma mass spectrometry (ICP-MS). The Keio knockout strains were grown for approximately $20 \mathrm{~h}$ on LB agar containing $50 \mu \mathrm{g} / \mathrm{mL}$ kanamycin. The wild type was grown for approximately $20 \mathrm{~h}$ on LB agar. One colony of the respective knockout strain was used to inoculate $2 \mathrm{~mL}$ of LB containing $50 \mu \mathrm{g} / \mathrm{mL}$ kanamycin. The wild type was inoculated into just $2 \mathrm{~mL}$ of LB. The overnight cultures were then diluted 1:1000 and grown to an OD 0.1. The resulting culture was then aliquoted into metal-free falcon tubes. The aliquoted cultures were treated with 0.5 or $4 \mu \mathrm{M}$ PT and/or $10 \mu \mathrm{M} \mathrm{CuCl}_{2}, \mathrm{ZnCl}_{2}$, ferric ammonium citrate for $15 \mathrm{~min}$ at $37^{\circ} \mathrm{C}, 200 \mathrm{rpm}$. Untreated samples were included for comparison. The cultures were centrifuged at $1000 \times g$ and $4{ }^{\circ} \mathrm{C}$ for $5 \mathrm{~min}$. The cells were then washed twice with $1 \mathrm{~mL}$ of metal-free water and once with $1 \mathrm{mM}$ EDTA. Cells were dried overnight at $80-90^{\circ} \mathrm{C}$. Cells were digested in $100 \mu \mathrm{L}$ of concentrated trace metal-grade nitric acid for $1-2 \mathrm{~h}$. Then, $900 \mu \mathrm{L}$ of $1 \%$ trace metal-grade nitric acid was added, and the samples were stored at room temperature until ICP-MS analysis. ICP-MS analysis was performed in the OHSU Elemental Analysis Core using an Agilent 7700x equipped with an ASX 500 autosampler. The system was operated at a radio frequency power of $1550 \mathrm{~W}$, an argon plasma gas flow rate of $15 \mathrm{~L} / \mathrm{min}$, and Ar carrier gas flow rate of $0.9 \mathrm{~L} / \mathrm{min}$. Elements were measured in kinetic energy discrimination (KED) mode using He gas $(4.3 \mathrm{~mL} \mathrm{~L} / \mathrm{min})$. Data were quantified using weighed, serial dilutions of a multi-element standard (CEM 2, (VHG labs, VHG-SM70B-100) Mn, Fe, Cu, Zn) and a single element standard for P (VHG labs, PPN-500). For each sample, data were acquired in triplicates and averaged. A coefficient of variance $(\mathrm{CoV})$ was determined from frequent measurements of a sample containing 
$\sim 10 \mathrm{ppb}$. An internal standard (Sc, Ge, Bi) continuously introduced with the sample was used to correct for detector fluctuations and to monitor plasma stability. Accuracy of the calibration curve was assessed by measuring NIST reference material (water, SRM 1643f) twice during the measurement and found to be within $\pm 10 \%$ for all determined elements. Data were normalised to the concentration of phosphorus for each sample.

Supplementary Materials: The following are available online. Table S1: Growth rate ratios of the membrane proteins subset of the E. coli Keio collection of gene knockouts challenged with $2 \mu \mathrm{M}$ pyrithione.

Author Contributions: Conceptualisation, J.E.S.-S., D.B.K. and J.Z.-B.; methodology, all authors; data analysis, J.E.S.-S. and A.T.R.R.; investigation, J.E.S.-S. and A.T.R.R.; resources, D.B.K. and K.J.F.; writing —original draft preparation, J.E.S.-S. and D.B.K.; writing—review and editing, all authors; visualisation, J.E.S.-S. and A.T.R.R.; funding acquisition, D.B.K. and K.J.F. All authors have read and agreed to the published version of the manuscript.

Funding: This research was funded in part by the National Institutes of Health (R01GM084176 to K.J.F.); J.M.Z.-B. acknowledges fellowship support from the Duke Pharmacological Sciences Training Program (T32 GM007105). D.B.K. thanks the Novo Nordisk Foundation for financial support (grant NNF20CC0035580).

Institutional Review Board Statement: Not applicable.

Informed Consent Statement: Not applicable.

Data Availability Statement: Data for growth of full Keio subset are in Table S1. Further raw data are available from corresponding authors.

Acknowledgments: We thank the Keuhn lab at Duke University for generously providing individual Keio deletions strains, and Hannah D'Ambrosio and the Derbyshire lab for their assistance with PCR. We thank Martina Ralle for collecting ICP-MS data at the Oregon Health Sciences University Elemental Analysis Core, with partial support from NIH instrumentation grant S10RR025512.

Conflicts of Interest: The authors declare no conflict of interest.

\section{References}

1. Holmes, A.H.; Moore, L.; Sundsfjord, A.; Steinbakk, M.; Regmi, S.; Karkey, A.; Guerin, P.; Piddock, L. Understanding the mechanisms and drivers of antimicrobial resistance. Lancet 2016, 387, 176-187. [CrossRef]

2. Mushtaq, A. UN commits to tackling antimicrobial resistance. Lancet Infect. Dis. 2016, 16, 1229-1230. [CrossRef]

3. Wells, V.; Piddock, L.J.V. Addressing antimicrobial resistance in the UK and Europe. Lancet Infect. Dis. 2017, 17, 1230-1231. [CrossRef]

4. Roope, L.S.J.; Smith, R.D.; Pouwels, K.B.; Buchanan, J.; Abel, L.; Eibich, P.; Butler, C.; Tan, P.S.; Walker, A.S.; Robotham, J.; et al. The challenge of antimicrobial resistance: What economics can contribute. Science 2019, 364, eaau4679. [CrossRef]

5. Baker, S. Infectious disease. A return to the pre-antimicrobial era? Science 2015, 347, 1064-1066. [CrossRef] [PubMed]

6. Tyers, M.; Wright, G.D. Drug combinations: A strategy to extend the life of antibiotics in the 21st century. Nat. Rev. Genet. 2019, 17, 141-155. [CrossRef]

7. Imai, Y.; Meyer, K.; Iinishi, A.; Favre-Godal, Q.; Green, R.; Manuse, S.; Caboni, M.; Mori, M.; Niles, S.; Ghiglieri, M.; et al. A new antibiotic selectively kills Gram-negative pathogens. Nature 2019, 576, 459-464. [CrossRef]

8. Baker, S.; Thomson, N.; Weill, F.-X.; Holt, K.E. Genomic insights into the emergence and spread of antimicrobial-resistant bacterial pathogens. Science 2018, 360, 733-738. [CrossRef]

9. Piddock, L.; Garneau-Tsodikova, S.; Garner, C. Ask the experts: How to curb antibiotic resistance and plug the antibiotics gap? Future Med. Chem. 2016, 8, 1027-1032. [CrossRef]

10. Annunziato, G. Strategies to overcome antimicrobial resistance (AMR) making use of non-essential target inhibitors: A review. Int. J. Mol. Sci. 2019, 20, 5844. [CrossRef]

11. Salcedo-Sora, J.E.; Kell, D.B. A quantitative survey of bacterial persistence in the presence of antibiotics: Towards antipersister antimicrobial discovery. Antibiotics 2020, 9, 508. [CrossRef] [PubMed]

12. Mendes, P.; Girardi, E.; Superti-Furga, G.; Kell, D.B. Why most transporter mutations that cause antibiotic resistance are to efflux pumps rather than to import transporters. bioRxiv 2020. [CrossRef]

13. Kell, D.B.; Swainston, N.; Pir, P.; Oliver, S.G. Membrane transporter engineering in industrial biotechnology and whole cell biocatalysis. Trends Biotechnol. 2015, 33, 237-246. [CrossRef]

14. Kell, D.B. Control of Metabolite Efflux in Microbial Cell Factories. Current Advances and Future Prospects, 1st ed.; CRC Press: Boca Raton, FL, USA, 2019. 
15. Piddock, L.J.V. Clinically Relevant Chromosomally Encoded Multidrug Resistance Efflux Pumps in Bacteria. Clin. Microbiol. Rev. 2006, 19, 382-402. [CrossRef] [PubMed]

16. Piddock, L.J.V. The 2019 Garrod lecture: MDR efflux in gram-negative bacteria-How understanding resistance led to a new tool for drug discovery. J. Antimicrob. Chemother. 2019, 74, 3128-3134. [CrossRef] [PubMed]

17. Ahmad, I.; Nawaz, N.; Dermani, F.K.; Kohlan, A.K.; Saidijam, M.; Patching, S.G. Bacterial multidrug efflux proteins: A major mechanism of antimicrobial resistance. Curr. Drug Targets 2018, 20, 16-28. [CrossRef]

18. Phillips-Jones, M.K.; Harding, S.E. Antimicrobial resistance (AMR) nanomachines-Mechanisms for fluoroquinolone and glycopeptide recognition, efflux and/or deactivation. Biophys. Rev. 2018, 10, 347-362. [CrossRef]

19. Poole, K. Efflux pumps as antimicrobial resistance mechanisms. Ann. Med. 2007, 39, 162-176. [CrossRef]

20. Rahman, T.; Yarnall, B.; Doyle, D.A. Efflux drug transporters at the forefront of antimicrobial resistance. Eur. Biophys. J. 2017, 46, 647-653. [CrossRef]

21. Willers, C.; Wentzel, J.; du Plessis, L.; Gouws, C.; Hamman, J.H. Efflux as a mechanism of antimicrobial drug resistance in clinical relevant microorganisms: The role of efflux inhibitors. Expert Opin. Ther. Targets 2017, 21, 23-36. [CrossRef]

22. Vrancianu, C.O.; Gheorghe, I.; Dobre, E.-G.; Barbu, I.C.; Cristian, R.E.; Popa, M.; Lee, S.H.; Limban, C.; Vlad, I.M.; Chifiriuc, M.C. Emerging strategies to combat $\beta$-lactamase producing ESKAPE pathogens. Int. J. Mol. Sci. 2020, 21, 8527. [CrossRef]

23. Gharavi, M.J.; Zarei, J.; Roshani-Asl, P.; Yazdanyar, Z.; Sharif, M.; Rashidi, N. Comprehensive study of antimicrobial susceptibility pattern and extended spectrum beta-lactamase (ESBL) prevalence in bacteria isolated from urine samples. Sci. Rep. 2021, 11, 578 [CrossRef]

24. Eiamphungporn, W.; Schaduangrat, N.; Malik, A.A.; Nantasenamat, C. Tackling the antibiotic resistance caused by class A $\beta$-lactamases through the use of $\beta$-lactamase inhibitory protein. Int. J. Mol. Sci. 2018, 19, 2222. [CrossRef]

25. Li, L.; Ye, L.; Kromann, S.; Meng, H. Occurrence of extended-spectrum $\beta$-lactamases, plasmid-mediated quinolone resistance, and disinfectant resistance genes in Escherichia coli isolated from ready-to-eat meat products. Foodborne Pathog. Dis. 2017, 14, 109-115. [CrossRef]

26. Wright, G.D. Antibiotic adjuvants: Rescuing antibiotics from resistance. Trends Microbiol. 2016, 24, 862-871. [CrossRef]

27. Lemire, J.A.; Harrison, J.; Turner, R.J. Antimicrobial activity of metals: Mechanisms, molecular targets and applications. Nat. Rev. Microbiol. 2013, 11, 371-384. [CrossRef]

28. Vincent, M.; Duval, R.; Hartemann, P.; Engels-Deutsch, M. Contact killing and antimicrobial properties of copper. J. Appl. Microbiol. 2018, 124, 1032-1046. [CrossRef] [PubMed]

29. Arendsen, L.P.; Thakar, R.; Sultan, A.H. The use of copper as an antimicrobial agent in health care, including obstetrics and gynecology. Clin. Microbiol. Rev. 2019, 32, e00125-18. [CrossRef] [PubMed]

30. Portelinha, J.; Duay, S.S.; Yu, S.I.; Heilemann, K.; Libardo, M.D.J.; Juliano, S.A.; Klassen, J.L.; Angeles-Boza, A.M. Antimicrobial peptides and copper(II) ions: Novel therapeutic opportunities. Chem. Rev. 2021, 121, 2648-2712. [CrossRef] [PubMed]

31. Gant, V.A.; Wren, M.W.D.; Rollins, M.S.M.; Jeanes, A.; Hickok, S.S.; Hall, T.J. Three novel highly charged copper-based biocides: Safety and efficacy against healthcare-associated organisms. J. Antimicrob. Chemother. 2007, 60, 294-299. [CrossRef]

32. Grass, G.; Rensing, C.; Solioz, M. Metallic copper as an antimicrobial surface. Appl. Environ. Microbiol. 2011, 77, 1541-1547. [CrossRef]

33. Wiebelhaus, N.; Zaengle-Barone, J.M.; Hwang, K.K.; Franz, K.J.; Fitzgerald, M.C. Protein folding stability changes across the proteome reveal targets of cu toxicity in E. coli. ACS Chem. Biol. 2021, 16, 214-224. [CrossRef]

34. Zaengle-Barone, J.M.; Jackson, A.C.; Besse, D.M.; Becken, B.; Arshad, M.; Seed, P.C.; Franz, K.J. Copper influences the antibacterial outcomes of a $\beta$-lactamase-activated prochelator against drug-resistant bacteria. ACS Infect. Dis. 2018, 4, 1019-1029. [CrossRef]

35. Quezada, L.L.; Li, K.; McDonald, S.L.; Nguyen, Q.; Perkowski, A.J.; Pharr, C.W.; Gold, B.; Roberts, J.; McAulay, K.; Saito, K.; et al Dual-pharmacophore pyrithione-containing cephalosporins kill both replicating and nonreplicating mycobacterium tuberculosis. ACS Infect. Dis. 2019, 5, 1433-1445. [CrossRef]

36. Helsel, M.E.; White, E.J.; Razvi, S.Z.A.; Alies, B.; Franz, K.J. Chemical and functional properties of metal chelators that mobilize copper to elicit fungal killing of Cryptococcus neoformans. Metallomics 2017, 9, 69-81. [CrossRef]

37. Oliveri, V. Biomedical applications of copper ionophores. Coord. Chem. Rev. 2020, 422, 213474. [CrossRef]

38. Djoko, K.Y.; Achard, M.E.S.; Phan, M.-D.; Lo, A.W.; Miraula, M.; Prombhul, S.; Hancock, S.J.; Peters, K.M.; Sidjabat, H.E.; Harris, P.N.; et al. Copper ions and coordination complexes as novel carbapenem adjuvants. Antimicrob. Agents Chemother. 2018, 62, e02280-17. [CrossRef] [PubMed]

39. Chandler, C.J.; Segel, I.H. Mechanism of the antimicrobial action of pyrithione: Effects on membrane transport, ATP levels, and protein synthesis. Antimicrob. Agents Chemother. 1978, 14, 60-68. [CrossRef] [PubMed]

40. Reeder, N.L.; Kaplan, J.; Xu, J.; Youngquist, R.S.; Wallace, J.; Hu, P.; Juhlin, K.D.; Schwartz, J.R.; Grant, R.A.; Fieno, A.; et al. Zinc pyrithione inhibits yeast growth through copper influx and inactivation of iron-sulfur proteins. Antimicrob. Agents Chemother. 2011, 55, 5753-5760. [CrossRef] [PubMed]

41. Albert, A.; Rees, C.W.; Tomlinson, A.J. The influence of chemical constitution on antibacterial activity. VIII. 2-mercaptopyridine- $n$ oxide, and some general observations on metalbinding agents. Br. J. Exp. Pathol. 1956, 37, 500-511.

42. Lanthaler, K.; Bilsland, E.; Dobson, P.; Moss, H.J.; Pir, P.; Kell, D.B.; Oliver, S.G. Genome-wide assessment of the carriers in-volved in the cellular uptake of drugs: A model system in yeast. BMC Biol. 2011, 9, 70. [CrossRef] [PubMed] 
43. Winter, G.E.; Radic, B.; Mayor-Ruiz, C.; Blomen, A.V.; Jessen-Trefzer, C.; Kandasamy, R.K.; Huber, K.V.; Gridling, M.; Chen, D.; Klampfl, T.; et al. The solute carrier SLC35F2 enables YM155-mediated DNA damage toxicity. Nat. Chem. Biol. 2014, 10, 768-773. [CrossRef] [PubMed]

44. Giacomini, K.M.; Huang, S.M.; Tweedie, D.J.; Benet, L.Z.; Brouwer, K.L.; Chu, X.; Dahlin, A.; Evers, R.; Fischer, V.; Hillgren, K.M.; et al. Membrane transporters in drug development. Nat. Rev. Drug Discov. 2010, 9, 215-236. [PubMed]

45. Giacomini, K.M.; Galetin, A.; Huang, S.M. The international transporter consortium: Summarizing advances in the role of transporters in drug development. Clin. Pharmacol. Ther. 2018, 104, 766-771. [CrossRef] [PubMed]

46. Dobson, P.D.; Kell, D.B. Carrier-mediated cellular uptake of pharmaceutical drugs: An exception or the rule? Nat. Rev. Drug Discov. 2008, 7, 205-220. [CrossRef] [PubMed]

47. Dobson, P.; Lanthaler, K.; Oliver, S.G.; Kell, D.B. Implications of the dominant role of cellular transporters in drug uptake. Curr. Top. Med. Chem. 2009, 9, 163-184. [CrossRef]

48. Kell, D.B.; Dobson, P.D.; Bilsland, E.; Oliver, S.G. The promiscuous binding of pharmaceutical drugs and their transportermediated uptake into cells: What we (need to) know and how we can do so. Drug Discov. Today 2013, 18, 218-239. [CrossRef]

49. Kell, D.B.; Oliver, S.G. How drugs get into cells: Tested and testable predictions to help discriminate between transporter-mediated uptake and lipoidal bilayer diffusion. Front. Pharmacol. 2014, 5, 231. [CrossRef]

50. Girardi, E.; César-Razquin, A.; Lindinger, S.; Papakostas, K.; Konecka, J.; Hemmerich, J.; Kickinger, S.; Kartnig, F.; Gürtl, B.; Klavins, K.; et al. A widespread role for SLC transmembrane transporters in resistance to cytotoxic drugs. Nat. Chem. Biol. 2020, 16, 469-478. [CrossRef]

51. Baba, T.; Ara, T.; Hasegawa, M.; Takai, Y.; Okumura, Y.; Baba, M.; Datsenko, A.K.; Tomita, M.; Wanner, B.L.; Mori, H. Construction of Escherichia coli K-12 in-frame, single-gene knockout mutants: The Keio collection. Mol. Syst. Biol. 2006, 2, 469-478. [CrossRef]

52. Yamamoto, N.; Nakahigashi, K.; Nakamichi, T.; Yoshino, M.; Takai, Y.; Touda, Y.; Furubayashi, A.; Kinjyo, S.; Dose, H.; Hasegawa, M.; et al. Update on the Keio collection of Escherichia coli single-gene deletion mutants. Mol. Syst. Biol. 2009, 5, 335. [CrossRef]

53. Kitagawa, M.; Ara, T.; Arifuzzaman, M.; Ioka-Nakamichi, T.; Inamoto, E.; Toyonaga, H.; Mori, H. Complete set of ORF clones of Escherichia coli ASKA library (A complete set of E. coli K-12 ORF archive): Unique resources for biological research. DNA Res. 2005, 12, 291-299. [CrossRef] [PubMed]

54. Mori, H.; Baba, T.; Yokoyama, K.; Takeuchi, R.; Nomura, W.; Makishi, K.; Otsuka, Y.; Dose, H.; Wanner, B.L. Identification of essential genes and synthetic lethal gene combinations in Escherichia coli K-12. Methods Mol. Biol. 2015, 1279, 45-65. [CrossRef]

55. Davey, H.M.; Kell, D.B. Flow cytometry and cell sorting of heterogeneous microbial populations: The importance of single-cell analysis. Microbiol. Rev. 1996, 60, 641-696. [CrossRef] [PubMed]

56. Jindal, S.; Thampy, H.; Day, P.J.R.; Kell, D.B. Very rapid flow cytometric assessment of antimicrobial susceptibility during the apparent lag phase of microbial (re)growth. Microbiology 2019, 165, 439-454. [CrossRef] [PubMed]

57. Jindal, S.; Yang, L.; Day, P.J.; Kell, D.B. Involvement of multiple influx and efflux transporters in the accumulation of cationic fluorescent dyes by Escherichia coli. BMC Microbiol. 2019, 19, 195. [CrossRef] [PubMed]

58. Salcedo-Sora, J.E.; Jindal, S.; O'Hagan, S.; Kell, D.B. A palette of fluorophores that are differentially accumulated by wild-type and mutant strains of Escherichia coli: Surrogate ligands for profiling bacterial membrane transporters. Microbiology 2021, 167, 001016. [CrossRef]

59. Khattar, M.; Salt, W.; Stretton, R. The influence of pyrithione on the growth of micro-organisms. J. Appl. Bacteriol. 1988, 64, 265-272. [CrossRef]

60. Ermolayeva, E.; Sanders, D. Mechanism of pyrithione-induced membrane depolarization in Neurospora crassa. Appl. Environ. Microbiol. 1995, 61, 3385-3390. [CrossRef]

61. Tarrant, E.; Riboldi, G.P.; McIlvin, M.R.; Stevenson, J.; Barwinska-Sendra, A.; Stewart, L.J.; Saito, M.A.; Waldron, K.J. Copper stress in Staphylococcus aureus leads to adaptive changes in central carbon metabolism. Metallomics 2019, 11, 183-200. [CrossRef]

62. Reeder, N.; Xu, J.; Youngquist, R.; Schwartz, J.; Rust, R.; Saunders, C. The antifungal mechanism of action of zinc pyrithione. Br. J. Dermatol. 2011, 165 (Suppl. 2), 9-12. [CrossRef]

63. Wijekoon, C.J.K.; Udagedara, S.R.; Knorr, R.L.; Dimova, R.; Wedd, A.G.; Xiao, Z. Copper ATPase CopA from Escherichia coli: Quantitative correlation between ATPase activity and vectorial copper transport. J. Am. Chem. Soc. 2017, 139, 4266-4269. [CrossRef]

64. Giachino, A.; Waldron, K.J. Copper tolerance in bacteria requires the activation of multiple accessory pathways. Mol. Microbiol. 2020, 114, 377-390. [CrossRef]

65. Rosenzweig, A.C.; Argüello, J.M. Toward a molecular understanding of metal transport by P1B-Type ATPases. Curr. Top Membr. 2012, 69, 113-136. [CrossRef]

66. Hou, Z.; Mitra, B. The metal specificity and selectivity of ZntA from Escherichia coli using the acylphosphate intermediate. J. Biol. Chem. 2003, 278, 28455-28461. [CrossRef] [PubMed]

67. Rensing, C.; Fan, B.; Sharma, R.; Mitra, B.; Rosen, B.P. CopA: An Escherichia coli Cu(I)-translocating P-type ATPase. Proc. Natl. Acad. Sci. USA 2000, 97, 652-656. [CrossRef]

68. Fan, B.; Rosen, B.P. Biochemical characterization of CopA, the Escherichia coli Cu(I)-translocating P-type ATPase. J. Biol. Chem. 2002, 277, 46987-46992. [CrossRef] [PubMed] 
69. Banci, L.; Bertini, I.; Baffoni, S.C.; Del Conte, R.; Gonnelli, L. Understanding copper trafficking in bacteria: Interaction between the copper transport protein CopZ and the N-terminal domain of the copper ATPase CopA from Bacillus subtilis. Biochemistry 2003, 42, 1939-1949. [CrossRef]

70. Padilla-Benavides, T.; Thompson, A.M.G.; McEvoy, M.M.; Argüello, J.M. Mechanism of ATPase-mediated Cu+ export and delivery to periplasmic chaperones: The interaction of Escherichia coli CopA and CusF. J. Biol. Chem. 2014, 289, 20492-20501. [CrossRef] [PubMed]

71. Radford, D.S.; Kihlken, M.A.; Borrelly, G.P.; Harwood, C.R.; Le Brun, N.; Cavet, J.S. CopZ from Bacillus subtilisinteracts in vivo with a copper exporting CPx-type ATPase CopA. FEMS Microbiol. Lett. 2003, 220, 105-112. [CrossRef]

72. Kirakosyan, G.; Trchounian, A. Redox sensing by Escherichia coli: Effects of copper ions as oxidizers on proton-coupled membrane transport. Bioelectrochemistry 2007, 70, 58-63. [CrossRef] [PubMed]

73. Wagner, S.; Bader, M.L.; Drew, D.; de Gier, J.-W. Rationalizing membrane protein overexpression. Trends Biotechnol. 2006, 24, 364-371. [CrossRef] [PubMed]

74. Grisshammer, R.; Tate, C. Overexpression of integral membrane proteins for structural studies. Q. Rev. Biophys. 1995, 28, 315-422. [CrossRef] [PubMed]

75. Beard, S.J.; Hashim, R.; Membrillo-Hernández, J.; Hughes, M.N.; Poole, R.K. Zinc(II) tolerance in Escherichia coli K-12: Evidence that the ZntA gene (o732) encodes a cation transport ATPase. Mol. Microbiol. 1997, 25, 883-891. [CrossRef] [PubMed]

76. Noll, M.; Lutsenko, S.; Noll, S.L.M. Expression of ZntA, a zinc-transporting P 1-type ATPase, is specifically regulated by zinc and cadmium. IUBMB Life 2000, 49, 297-302. [CrossRef] [PubMed]

77. Binet, M.R.; Poole, R.K. Cd(II), Pb(II) and $\mathrm{Zn}(\mathrm{II})$ ions regulate expression of the metal-transporting P-type ATPase ZntA in Escherichia coli. FEBS Lett. 2000, 473, 67-70. [CrossRef]

78. Dutta, S.J.; Liu, J.; Mitra, B. Kinetic analysis of metal binding to the amino-terminal domain of ZntA by monitoring metal-thiolate charge-transfer complexes. Biochemistry 2005, 44, 14268-14274. [CrossRef]

79. Sharma, R.; Rensing, C.; Rosen, B.P.; Mitra, B. The ATP hydrolytic activity of purified ZntA, a Pb(II)/Cd(II)/Zn(II)-translocating ATPase from Escherichia coli. J. Biol. Chem. 2000, 275, 3873-3878. [CrossRef]

80. Nguyen, P.T.; Lai, J.Y.; Lee, A.T.; Kaiser, J.T.; Rees, D.C. Noncanonical role for the binding protein in substrate uptake by the MetNI methionine ATP Binding Cassette (ABC) transporter. Proc. Natl. Acad. Sci. USA 2018, 115, E10596-E10604. [CrossRef]

81. Merlin, C.; Gardiner, G.; Durand, S.; Masters, M. The Escherichia coli metD Locus encodes an ABC transporter which includes Abc (MetN), YaeE (MetI), and YaeC (MetQ). J. Bacteriol. 2002, 184, 5513-5517. [CrossRef]

82. Carlson, M.L.; Stacey, R.G.; Young, J.W.; Wason, I.S.; Zhao, Z.; Rattray, D.G.; Scott, N.; Kerr, C.H.; Babu, M.; Foster, L.J.; et al Profiling the Escherichia coli membrane protein interactome captured in peptidisc libraries. Elife 2019, 8, e46615. [CrossRef] [PubMed]

83. Pierce, J.R.; Earhart, C.F. Escherichia coli K-12 envelope proteins specifically required for ferrienterobactin uptake. J. Bacteriol. 1986, 166, 930-936. [CrossRef] [PubMed]

84. R Core Team. R: A Language and Environment for Statistical Computing; R Foundation for Statistical Computing: Vienna, Austria, 2020; Available online: https: / / www.R-project.org/ (accessed on 16 June 2021).

85. Ritz, C.; Baty, F.; Streibig, J.C.; Gerhard, D. Dose-response analysis using R. PLoS ONE 2015, 10, e0146021. [CrossRef] [PubMed]

86. Sebaugh, J.L. Guidelines for accurate EC50/IC50 estimation. Pharm. Stat. 2011, 10, 128-134. [CrossRef]

87. Hall, B.G.; Acar, H.; Nandipati, A.; Barlow, M. Growth rates made easy. Mol. Biol. Evol. 2013, 31, 232-238. [CrossRef]

88. Vaas, L.A.I.; Sikorski, J.; Michael, V.; Göker, M.; Klenk, H.-P. Visualization and curve-parameter estimation strategies for efficient exploration of phenotype microarray kinetics. PLoS ONE 2012, 7, e34846. [CrossRef]

89. Petzoldt, T. Growthrates: Estimate Growth Rates from Experimental Data. 2020. Available online: https://github.com/tpetzoldt/ growthrates (accessed on 16 June 2021). 